\title{
3 Research Suare \\ Sevoflurane Modulates Akt Isoforms In Triple \\ Negative Breast Cancer Cell Line
}

\section{CRINA ELENA TIRON}

Regional Institute of Oncology

\section{Emilia Patrascanu}

Universitatea de Medicina si Farmacie Gr T Popa lasi Facultatea de Medicina https://orcid.org/00000002-0646-985X

\section{PAULA ALEXANDRA POSTU}

Regional Institute of Oncology

IRINA C. VACAREAN TRANDAFIR

Regional Institute of Oncology

ADRIAN TIRON ( $\square$ adrian.tiron@iroiasi.ro)

IOANA GRIGORAS

Universitatea de Medicina si Farmacie Gr.T.Popa lasi

\section{Research}

Keywords: AKT, breast cancer, EMT, HIF, sevoflurane, vimentin.

Posted Date: April 10th, 2020

DOI: https://doi.org/10.21203/rs.3.rs-21784/v1

License: (c) (i) This work is licensed under a Creative Commons Attribution 4.0 International License.

Read Full License 


\section{Abstract}

Background: Triple negative breast cancer (TNBC) is a highly aggressive tumor, associated with high rates of early distant recurrence and short survival times and treatment may require surgery, and thus anesthesia. The effects of anesthetic drugs on cancer progression are under scrutiny, but published data are controversial and the involved mechanisms unclear. Anesthetic agents have been shown to modulate several molecular cascades, including PI3K/AKT/mTOR. AKT isoforms are frequently amplified in various malignant tumors and associated with malignant cell survival, proliferation and invasion. Their activation is often observed in human cancers and is associated with decreased survival rate. Certain anesthetics are known to affect hypoxia cell signalling mechanisms by upregulating hypoxia-inducible factors (HIFs).

Methods: MCF-10A and MDA-MB 231 cells were cultivated and CellTiter-Blue® Cell Viability assay, 2D and 3D matrigel assay, immunofluorescence assays and gene expressions were performed after exposure to different sevoflurane concentrations.

Results: Sevoflurane exposure of triple negative breast cancer cells results in morphological and behavioral changes. Sevoflurane differently influences the AKT isoforms expression in a time-dependent manner, with an important early AKT3 upregulation. The most significant effects occur at 72 hours after $2 \mathrm{mM}$ sevoflurane treatment and consist in increased viability, proliferation and aggressiveness and increased vimentin and HIF expression.

Conclusion: Sevoflurane exposure during surgery may contribute to cancer recurrence via AKT3 induced EMT and by all three AKT isoforms enhanced cancer cell survival and proliferation.

\section{Background}

Multiple factors, both biological and therapy-related, influence cancer evolution and progression. Despite significant advances in oncological therapies, cancer remains a major cause of mortality. Tumor metastasis, a complex process that requires release of metastatic cells from a primary tumor, invasion and (local, lymphatic, intravascular) migration and subsequent extravasation and proliferation in target tissues, is accounted for $90 \%$ of cancer death [1-3]. Cellular and molecular events associated with the metastatic process may be significantly influenced by many factors during and immediately after surgery $[4,5]$. Surgical resection is a widely used treatment for solid tumors, including breast cancer. Various studies suggest that the choice of anesthesia technique/drugs could affect long-term outcome after surgery [6-8]. Deegan et al. demonstrated that serum of patients with breast cancer surgery, taking place under two different anesthesia techniques, induce different effects on cancer cell proliferation and migration, thus differently influencing cancer recurrence/metastasis [4]. Inhalational anesthetics and opiates analgesics have been associated with impaired immunity and increased tumor recurrence [9-12]. 
Certain anesthetics (e.g. isoflurane, sevoflurane, halothane) are known to affect hypoxia cell signaling mechanisms by up-regulating HIFs. HIFs are also implicated in tumorigenesis and metastasis influencing angiogenesis, energy metabolism, cell proliferation, apoptosis, and cell migration [13, 14]. Other anesthetics (e.g. propofol and etomidate) are able to stimulate the EMT initiation through the increment of mesenchymal markers expression [15]. Volatile anesthetics (e.g. halothane, isoflurane, sevoflurane) have been implicated in angiogenesis and immunosuppression, induced apoptosis of immune competent cells (NK cells and T-lymphocytes), but also have a promoting effect on tumor metastasis [10-16]. Although sevoflurane is nowadays the most frequently used inhaled anesthetic, its direct influence on cancerous cells is mainly unknown.

Anesthetic agents (e.g. isoflurane, sevoflurane) have been shown to modulate several molecular cascades in various tissues, including PI3K/AKT/mTOR $[17,18]$. AKT, also known as protein kinase $B$ (PKB), plays a key role in signaling downstream of growth factors and other stimuli, regulating critical cellular functions, including proliferation and survival. AKT abnormal hyperactivation by gene amplification or somatic mutation is frequently associated with human pathology, including cancer [19, 20].

In humans there are three AKT isoforms (AKT1, AKT2 and AKT3) containing the following four domains: $\mathrm{PH}$ domain, linker region, catalytic domain and C-terminal regulatory region. Most studies using individual knockout of those three isoforms suggested non-redundant functions of AKT proteins [20-28]. The mechanisms by which those isoform signalling can be conveyed are different: post-translational modifications, regulation of kinase activity, substrate specificity and subcellular localization [29-32].

In normal tissues AKT1 has a wide tissue distribution; AKT2 is highly expressed in adipocytes and muscle, whereas AKT3 is mainly expressed in the testes, lungs and brain [22, 25-35].

In cancer, AKT1 has been found to be overexpressed in human gastric, breast and ovarian cancers; AKT2 was amplified and overexpressed in ovarian, pancreatic, hepatic, colorectal cancer and glioma, while AKT3 has been reported in progression of breast, prostate, ovarian cancer, and malignant melanoma [3639]. Several studies have suggested that AKT family members serve distinct roles in invasion, migration and metastatic dissemination [40-43].

Therefore, in order to investigate the sevoflurane effects on tumor progression and metastasis, we performed an experimental study aiming to evaluate the effect of sevoflurane on AKT isoforms expression in human breast cancer cells and its effects on viability, proliferation, aggressivity and EMT.

\section{Matherials And Methods}

We designed an in vitro experiment using 2D and 3D cultures of two breast cell lines (a human cancer cell line and human normal breast cell line) exposed to different sevoflurane concentrations. 
We used a human breast adenocarcinoma cell line - MDA-MB-231 (ATCC $®$ ), a triple negative aggressive form of breast cancer, and normal human mammary epithelial cells - MCF-10A (ATCC $®$ ).

All cell cultures, both cancer and normal cells, were divided in 5 groups handled in the same manner: without sevoflurare exposure (G1) and with sevoflurane exposure - 0,5 mM (G2), 1 mM (G3), 2 mM (G4) and $4 \mathrm{mM}$ (G5). All 2D groups were assessed at the end of $6 \mathrm{~h}$ exposure, and 24, and 72 hours after exposure for AKT expression, cell viability and proliferation, EMT by vimentin expression and HIF-1a expression. All 3D groups were assessed for cell phenotype.

\section{Reagents}

Horse serum (Sigma), EGF (Sigma), insulin (Sigma), hydrocortisone (Sigma), cholera toxin (Sigma), Pen/Strep (Sigma), bovine serum (Sigma-Aldrich), CellTiter-Blue® Cell Viability Assay (Promega), Matrigel (Cornning), rabbit polyclonal anti-human AKT1 antibody (Sigma Aldrich, SAB3500216), rabbit polyclonal anti-human AKT2 antibody (Sigma Aldrich, SAB4300423), rabbit monoclonal anti-human AKT3 antibody (Cell Signaling Technology, E1Z3W), rabbit monoclonal anti-human Vimentin antibody (Cell Signaling Technology, D21H3), rabbit monoclonal anti-human Hif-1a antibody (Abcam, 179483), fluorescein goat anti-rabbit IgG (ThermoFisher Scientific, F2765), Prolong (R) Gold antifade with DAPI (Cell Signaling Technology, 8961S), 4\% paraformaldehyde (Sigma Aldrich), PBS (Santa Cruz), saponin (Merck), Triton X 100 (Roth), digitonin (Promega), goat serum (Dako), Fetal bovine serum (Sigma), TRIzol (Invitrogen), First Strand cDNA Synthesis Kit (Invitrogen), Power SYBR Green PCR Master Mix (Applied Biosystems $^{\mathrm{TM}}$ ).

\section{Cell culture}

MCF-10A cells were cultured in DMEM/F12 supplemented with $5 \%$ horse serum, $20 \mathrm{ng} / \mathrm{ml} \mathrm{EGF,} \mathrm{10ug/ml}$ insulin, $0.5 \mathrm{ng} / \mathrm{ml}$ hydrocortisone, $10 \mathrm{ng} / \mathrm{ml}$ cholera toxin, $1 \%$ Pen/Strep. MDA-MB-231 cells were cultured in F-12K Medium, supplemented with $100 \mathrm{U} / \mathrm{mL}$ of penicillin and $100 \mu \mathrm{g} / \mathrm{mL}$ of streptomycin and $5 \%$ bovine serum.

\section{Cell viability and sevoflurane exposure}

Cells were seeded into a 96-well flat bottom tissue culture plate at a density of 2000 cells/well and allowed to adhere to the plate by incubating at $37^{\circ} \mathrm{C}$ under $5 \% \mathrm{CO}_{2}$ overnight. Following cell attachment, the cells were incubated for $6 \mathrm{~h}$ with a sevoflurane solution having one of the following concentrations: $0.5,1,2$ and $4 \mathrm{mM}$. After $6 \mathrm{~h}$ exposure, $50 \mu \mathrm{L}$ of cell viability solution (CellTiter-Blue ${ }^{\circledR}$ Cell Viability Assay) was added to each well and the plate was reincubated for $4 \mathrm{~h}$ before fluorescence recording.

\section{The 3D matrigel assays}

1000 cells were seeded in Ibidi plates, between 2 layers of Matrigel (BD Matrigel Matrix, Growth Factor Reduced (BD Biosciences)) and cultured for 14 days before microscopy analysis (TissueGnostic rig). $12 \mathrm{~h}$ post seeding $3 \mathrm{D}$ embedded cells were treated with a sevoflurane solution at concentrations either $0.5,1,2$ 
or $4 \mathrm{mM}$ for $6 \mathrm{~h}$. After $6 \mathrm{~h}$ the sevoflurane solution was removed and replaced with normal 3D matrigel medium (medium corresponding to every cell type supplemented with $2 \%$ FBS and $1 \%$ matrigel).

\section{Immunofluorescence}

Several 96-well flat bottom culture plates were seeded with MCF-10A (one half of the plate) and MDA-MB231 cells (the other half of the plate) in $2 \mathrm{D}$ culture system at $37^{\circ} \mathrm{C}$ under $5 \% \mathrm{CO}_{2}$, each well containing 2000 cells. One plate was used as control and was not exposed to sevoflurane.

After $24 \mathrm{~h}$, plates containing attached cells were treated by incubation with $2 \mathrm{mM}$ sevoflurane solution for $6 \mathrm{~h}$ and each plate was fixed with $4 \%$ paraformaldehyde at a different time points: either immediately after sevoflurane treatment, at $24 \mathrm{~h}$ or at $72 \mathrm{~h}$ post sevoflurane exposure. For each corresponding fixation point we fixed MCF-10A and MDA-MB-231 cells from parallel 2D untreated cultures (unexposed plate). After cell fixation, the plates were washed with PBS for 5 minutes at room temperature. For immunofluorescence staining the cell membranes were permeabilized for $2 \mathrm{~h}$ at room temperature using a permeabilization solution containing $0,3 \%$ saponin, $0,3 \%$ Triton $X 100$ and $0,3 \%$ digitonin. Diluted primary antibodies, anti-AKT1 (1:25), anti-AKT2 (1:25), anti-AKT3 (1:25), anti-vimentin (1:15) and anti-HIF$1 \mathrm{a}(1: 25)$ were incubated for $72 \mathrm{~h}$ at $4^{\circ} \mathrm{C}$. These antibodies were diluted using an antibody dilution solution containing $0,3 \%$ saponin, $0,3 \%$ Triton $X 100$ and $0,5 \%$ goat serum. The cells were washed twice with PBS (each washing step lasted for 5 minutes) and incubated with fluorescein goat anti-rabbit IgG (1:200) for $24 \mathrm{~h}$ at $4^{\circ} \mathrm{C}$ (the antibody was diluted using an antibody dilution solution containing $0,3 \%$ saponin, $0,3 \%$ Triton $X 100$ and $2 \%$ fetal bovine serum). After fluorescein goat anti-rabbit IgG removal, cells were washed twice with PBS (each washing step had a 5 minute duration) and the fluorescent dye was protected by incubating over night at $4^{\circ} \mathrm{C}$ with Prolong $(\mathrm{R})$ Gold antifade with DAPI.

\section{Quantitative RT-PCR (qRT-PCR) analysis}

Molecular biology techniques were used to determine changes in HIF-1a expression in MDA-MB-231 cells, by assessing gene expression for specific molecular targets.

Total RNA extraction from $10^{7}$ cells was performed using TRIzol. The cells were lysed, and RNA purification was performed according to the manufacturer's protocol. Total RNA concentration was measured by spectrophotometry at $260 \mathrm{~nm}$ and the RNA was stored at $20^{\circ} \mathrm{C}$ until reverse transcription in cDNA was performed. cDNA was synthesized using the First Strand cDNA Synthesis Kit using the Corbett CGI-96 Palm-Cycler Thermal Cycler equipment. The complementary DNA obtained was used immediately or stored for a short time at $20^{\circ} \mathrm{C}$ or for a longer term at $80^{\circ} \mathrm{C}$.

Quantitative Real-time PCR amplification was performed on a LightCycler 480 II (Roche) using the following primer pairs for HIF-1a: Fw: 5'-CACTACCACTGCCACCACTG-3' and Rev: 5'-

CCTTTTCCTGCTCTGTTTGG-3'. For the reaction, $5 \mu \mathrm{L}$ of cDNA were incubated with $12.5 \mu \mathrm{L}$ of Power SYBR Green PCR Master Mix and $1 \mu \mathrm{L}$ of forward and reverse primers in a final volume of $25 \mu \mathrm{L}$. The primer melting temperature was $60^{\circ}$ and the analysis was performed in triplicate. The obtained amplicons of different concentrations through RTPCR amplification were compared to the concentration 
of $A B L$ reference gene. The results were reported as percentages of increase/decrease of the gene expression compared to the control, as compared to the reference gene $(A B L)$ : \% gene $=$ number of amplicon genes/ $\mu \mathrm{l} /$ reference gene $(A B L) \times 100$.

\section{Statistical analysis}

Statistical analysis was performed with GraphPad Prism 7, ttest. Data analysis results are presented as the mean \pm S.E.M. Significance was established when $p<0.05$.

\section{Results}

\section{Sevoflurane exposure modulates cells viability and proliferation rate}

We assessed the sevoflurane effects on cell viability and cell proliferation rate of triple negative breast cancer cell line MDA-MB-231 and normal breast cell line MCF-10A in 2D culture system. Viability of normal mammary epithelial cells (MCF-10A) was unaffected by $0.5-2 \mathrm{mM}$ sevoflurane concentrations at $24 \mathrm{~h}$ and $72 \mathrm{~h}$ (Fig. 1A), while $4 \mathrm{mM}$ concentration significantly reduced number and altered cell phenotype. In human breast adenocarcinoma cell line (MDA-MB-231) viability was dynamic, significantly decreasing $24 \mathrm{~h}$ post sevoflurane exposure (Fig. 1B) and significantly increasing at $72 \mathrm{~h}$ post sevoflurane treatment (Fig. 1C), results observed at all concentrations.

The most significant changes have been observed in the cells treated with $2 \mathrm{mM}$ sevoflurane concentration (Figure 1B4-C4). Moreover, the sevoflurane exposed MDA-MB-231 cells acquired an uncharacteristic round shape at $24 \mathrm{~h}$ and they recovered their mesenchymal-like phenotype at $72 \mathrm{~h}$ time point (Figure 2B, Supp. Fig.1).

These data indicate that different sevoflurane concentrations reduced proliferation rate of breast cancer cells and their morphological phenotype dramatically changed.

\section{Sevoflurane exposure increases aggressivity}

Because there is a correlation between sevoflurane concentration and cancer cell proliferation in 2D system, we evaluated the effect of sevoflurane in a 3D matrigel model. Our data demostrate that, with increasing sevoflurane concentration, the breast carcinoma cell line (MDA-MB-231) form large colonies with a higher number of invasive cell projection, particularly at 2mM (Figure 2B_4), indicating a migratory behavior with increased aggressiveness, as shown by Gjerdrum [44].

On the contrary, the sevoflurane exposed normal mammary cells (MCF10A) maintained the same spheroidal phenotype as the untreated MCF10A cells (Figure 3A), while the number of spheroids was reduced by $4 \mathrm{mM}$ sevoflurane administration (Figure 3A_5). 
Together, these findings suggest that high sevoflurane level amplify the mesenchymal-like invasiveness of metastatic breast carcinoma cells.

\section{Sevoflurane exposure affects AKT isoforms expression}

We assessed the influence of $2 \mathrm{mM}$ sevoflurane concentrations on AKT isoforms expression. This concentration was chosen based on the above mentioned results, showing that cancer cells presented the most robust proliferation changes at $2 \mathrm{mM}$ sevoflurane concentration.

In normal breast cells sevoflurane exposure has different impact on the three AKT isoforms expression. AKT1 level was significantly reduced at 72 hours (Figure 3A_6, Supp. Fig.2A), AKT2 was significantly upregulated by sevoflurane treatment at all timepoints (Figure 3B_2,4,6, Supp. Fig.3A), while AKT3 expression was not affected (Figure 4C, Supp. Fig.4A).

In the triple negative breast cancer cells sevoflurane exposure dynamically adjusts the AKT isoforms expression (Figure 5 A, B, C, Supp. Fig.2,3,4B). At the end of 6 hours treatment a significant drop in AKT1 and AKT2 expressions was observed (Figure 5 A, B_2). On the other hand, at the same time point a major upregulation in AKT3 isoform expression was noticed (Figure 5 C_2). Later, at 24 hours, AKT1 expression was further downregulated (Figure 5 A_4) and the AKT3 expression was further upregulated (Figure 5 C_4), the AKT2 shifted its expression pattern being significantly increased (Figure 5 B_4). Although the expression levels vary greatly between AKT isoforms, sevoflurane showed no influence at 72 hours on MDA-MB-231 cells, sevoflurane exposed and unexposed cells presenting a similar expression of AKT1, AKT2 or AKT3 isoforms (Figure 5 A, B, C_6). Altogether, these results suggest that the sevoflurane exposure highly influences the AKT isoformes expression in the first 24 hours.

\section{Sevoflurane differently regulates intermediate filaments (IFs) proteins levels}

We demonstrate that sevoflurane treatment modulates vimentin, a mesenchymal-specific IFs protein, expression in triple negative breast cancer cells. Sevoflurane exposed versus unexposed MDA-MB-231 cells show at 6 hours a significant increase in vimentin expression (Figure 6 B_2, Supp. Fig. 5B) and then, at $24 \mathrm{~h}$ vimentin expression dropped, having a similar expression level as untreated MDA-MB-231 cells (Figure 6 B_4, Supp. Fig. 5B). Surprisingly, at $72 \mathrm{~h}$ a significant vimentin expression burst was detected in MDA-MB-231 cells (Figure 6B_6, Supp. Fig. 5B).

Regarding non-malignant MCF-10A breast cells, the vimentin expression presented a decreasing trend over the $72 \mathrm{~h}$ experiment despite sevoflurane administration (Figure $6 \mathrm{~A}$, Supp. Fig. 5A).

The significantly increased levels of Vimentin protein expression at 72 hours demonstrates that sevoflurane exposure induce EMT via AKT3 isoform. 


\section{Sevoflurane exposure modulates HIF-1a expression}

In our experimental setup we found an increased HIF-1a genes (Figure 7A) and protein expression (Figure 7B) at 72 hours after sevoflurane exposure in cancer cell lines.

\section{Discussions}

Inhaled anesthetics are frequently used in different types of surgery, including oncological surgery, despite emerging evidence of potential deleterious effects. Although sevoflurane is the mostly used volatile agent due to its pharmacokinetic and pharmacodynamic advantages, little is known about its influence on cancer cells. Identifying the effects of the inhaled anesthetics on tumor cells will improve understanding of tumor recurrence/metastasis after surgery and may lead to changes in clinical practice. In this study, we investigated the effects of sevoflurane on triple negative breast cell line and some of the potential mechanisms involved.

Treating triple negative breast cancer, a subtype of breast cancer that lacks the receptors for estrogen, progesterone and HER2 (human epidermal growth factor receptor 2), remains challenging although great progresses were done over the recent years [45]. Being either lumpectomy or mastectomy, oncosurgery remains an effective treatment for primary breast tumor removal [46], so anesthesia is unavoidable. The Ecimovic et al. in vitro study showed that sevoflurane affects human triple positive and triple negative breast cancer cells, suggesting that volatile anesthetics may induce tumorigenic effects [47]. Similarly, we demonstrated that sevoflurane promoted the proliferation of the MDA-MB-231 cells. Moreover, we showed that sevoflurane enhanced the aggressive behavior of triple negative breast cancer cells in 3D matrigel assay. Other studies reported that in certain tumor cells (lung, pancreas, colon [48-50]) sevoflurane inhibited tumor growth and those results could be explained by differences in to cell type, time of exposure, concentration, etc. Our data demonstrate that initially ( 24 hours post sevoflurane exposure) sevoflurane indeed inhibited cancer cell proliferation, while at 72 hours there is a significant increase of proliferation and changes in morphological phenotype. These phenomena did not occur in normal breast cell line, except $4 \mathrm{mM}$ concentration. We speculate that, high sevoflurane concentration $(2 \mathrm{mM})$ induces EMT and concomitantly increased activity of cancer stem cell population, which in the end will promote invasiveness and cancer aggressiveness.

To elucidate the underlying mechanism, we examined the effects of sevoflurane on AKT isoforms, which were reported to be involved in major cellular processes [17-28]. The overexpression of AKT isoforms in different types of malignancies is well documented [51]. While different studies revealed different results regarding the involvement of AKT1 and AKT2 in mammary carcinomas, AKT3 dysfunctions are often correlated with triple negative breast cancer [52]. Our study demonstrates a time-dependent expression of AKT1,2,3 in MDA-MB 231 cells after 2mM sevoflurane exposure. It has been reported that AKT1 does not promote invasive phenotype, while AKT3 is required for TNBC proliferation and tumor growth [43]. Congruent with this observation we found a significant drop in AKT1 at 6 and 24 hour post $2 \mathrm{mM}$ sevoflurane exposure and only AKT3 isoform was significantly upregulated at those time points. 
Recent studies showed that intermediate filaments (IFs) are involved in signalling pathways which regulate cell growth, resistance to apoptosis and motility. Vimentin, a mesenchymal-specific IFs protein, is a distinct feature of EMT [53]. The EMT activation is correlated with molecular changes as shifts in cadherins expression [54], cytokeratin loss, vimentin and collagen increased expressions [53,55]. Moreover, PI3K-AKT pathway are essential to maintain the CSC-like phenotype and EMT characteristics in breast cancer cells [56]. Sevoflurane significantly enhances EMT, as demonstrated by upregulation of its commonly used marker, vimentin, at 6 and 72 hour post sevoflurane exposure. This further support the AKT3 key role in sevoflurane induced tumor growth, invasion and tumor recurrence.

The volatile anesthetics upregulate HIFs [10-16] and HIF overexpression is associated with an unfavorable prognosis in breast cancer $[57,58]$. HIF-1 a has been found to promote EMT in many human malignancies leading to increased cancer aggressiveness [59]. Also, PI3K/AKT and the MAP kinase Erk1/2, have been implicated in upregulating of HIF-1a [17]. Here we demonstrate that $2 \mathrm{mM}$ sevoflurane exposure increases HIF-1a genes and protein expression. In our design, HIF-1a further validates that sevoflurane exposure induces EMT.

Our in vitro study investigates sevoflurane effects on breast normal and cancer cells and some of the involved mechanisms. Our results open the way to further research, which should investigate in vivo the cumulative effects of anaesthetics, surgery and related factors, but also the interplay of effects on cancer cells and on immune system.

\section{Conclusions}

Our study demonstrates that in vitro sevoflurane exposure of triple negative breast cancer cells results in morphological and behavioral changes. Sevoflurane differently influences the AKT isoforms expression in a time-dependent manner, with an important early AKT3 upregulation. The most significant effects occur at 72 hours after $2 \mathrm{mM}$ sevoflurane treatment and consist in increased viability, proliferation and aggressiveness and increased vimentin and HIF expression. Thus, we may conclude that sevoflurane exposure during surgery may contribute to cancer recurrence via AKT3 induced EMT and by all three AKT isoforms enhanced cancer cell survival and proliferation.

\section{List Of Abbreviations}

TNBC - Triple Negative Breast Cancer

HIFs - Hypoxia-Inducible Factors

EMT - Epithelial to Mesenchimal Transition

\section{Declarations}

Ethics approval and consent to participate - "Not applicable" 
Consent for publication - "Not applicable"

Availability of data and materials- "Not applicable"

Conflicts of interest/Competing interests - "The authors declare that they have no competing interests"

Funding - This work was funded by"Grigore T. Popa" University of Medicine and Pharmacy, lasi, Romania (grant 30333/28.12.2017, coordinator Emilia Patrascanu).

Authors' contributions - In vitro experiments, bright field imaging, immunofluorescence, gene expression and results interpretation: C.E.T., P.A.P., A.T. and I.C.V.T. Writing and editing of the manuscript: C.E.T., E.P., A.T., P.A.P. and I.G. Conceptualization and supervision: I.G. All authors have given approval to the final version of the manuscript.

Acknowledgements - This work was funded by "Grigore T. Popa" University of Medicine and Pharmacy, lasi, Romania (grant 30333/28.12.2017, coordinator Emilia Patrascanu).

\section{References}

1. Nieto MA, Huang RY, Jackson RA, Thiery JP (2016). EMT: 2016. Cell 166(1):21-45.

2. Mitra A, Mishra L, Li S (2015). EMT, CTCs and CSCs in tumor relapse and drug-resistance. Oncotarget 6(13):10697-10711.

3. Bill R, Christofori G. (2015). The relevance of EMT in breast cancer metastasis: Correlation or causality? FEBS Lett 589(14):1577-87.

4. Deegan CA, Murray D, Doran P, Ecimovic P, Moriarty DC, Buggy DJ (2009). Effect of anaesthetic technique on oestrogen receptor-negative breast cancer cell function in vitro. $\mathrm{Br} J$ Anaesth 103(5):685-90.

5. Shi QY, Zhang SJ, Liu L, Yu LN, Zhang FJ, Yan M (2015). Sevoflurane promotes the expansion of glioma stem cells through activation of hypoxia-inducible factors in vitro. $\mathrm{Br} J$ Anaesth 114(5):82530 .

6. Enlund M, Berglund A, Andreasson K, Cicek C, Enlund A, Bergkvist L. The choice of anaestheticsevoflurane or propofol-and outcome from cancer surgery: a retrospective analysis (2014). Ups J Med Sci 119(3):251-261.

7. Wigmore TJ, Mohammed K, Jhanji S (2016). Long-term Survival for Patients Undergoing Volatile versus IV Anesthesia for Cancer Surgery: A Retrospective Analysis. Anesthesiology 124(1):69-79.

8. Lee JH, Kang SH, Kim Y, Kim HA, Kim BS (2016). Effects of propofol-based total intravenous anesthesia on recurrence and overall survival in patients after modified radical mastectomy: a retrospective study. Korean J Anesthesio/ 69(2):126-132.

9. Shavit Y, Ben-Eliyahu S, Zeidel A, Bellin B (2004). Effects of fentanyl on natural killer cell activity and on resistance to tumor metastasis in rats. Dose and timing study. Neuroimmunomodulation 
11(4):255-60.

10. Melamed R, Bar-Yosef S, Shakhar G, Shakhar K, Ben-Eliyahu (2003). Suppression of natural killer cell activity and promotion of tumor metastasis by ketamine, thiopental, and halothane, but not by propofol: mediating mechanisms and prophylactic measures. Anesth Analg 97(5):1331-9.

11. Horowitz M, Neeman E, Sharon E, Ben-Eliyahu S (2015). Exploiting the critical perioperative period to improve long term cancer outcomes. Nat Rev Clin Oncol 12(4):213-226.

12. Exadaktylos AK, Buggy DJ, Moriartry DC, Mascha E, Sessler DI (2006). Can anesthetic technique for primary breast cancer surgery affect recurrence or metastasis?Anesthesiology 105(4):660-664.

13. Tavare AN, Perry NJ, Benzonana LL, Takata M, Ma D (2012). Cancer recurrence after surgery: Direct and indirect effects of anesthetic agents. Int J Cancer 130(6):1237-1250.

14. Ryungsa Kim (2018). Effects of surgery and anesthetic choice on immunosuppression and cancer recurrence. J Transl Med 16(1):8-8.

15. Deng F, Ouyang M, Wang X, Yao X, Chen $Y$ et al (2016). Differential role of intravenous anesthetics in colorectal cancer progression: implications for clinical application. Oncotarget 7(47):77087-77095.

16. Bajwa SJ, Anand S, Kaur G (2015). Anesthesia and cancer recurrences: The current knowledge and evidence. J Cancer Res Ther 11(3):528-534.

17. Zhang L, Zhang J, Dong Y, Swain CA et al (2014). The potential dual effects of sevoflurane on AKT/GSK3 $\beta$ signaling pathway. Med Gas Res 4(1):5-5.

18. Hu J, Hu Ji, Jiao H, Li Q (2018). Anesthetic effects of isoflurane and the molecular mechanism underlying isoflurane-inhibited aggressiveness of hepatic carcinoma. Mol Med Rep 18(1):184-192.

19. Manning BD, Cantley LC (2007). AKT/PKB signaling: navigating downstream. Cell 129(7):1261-1274.

20. Fedele CG, Ooms LM, Ho M, Vieusseux J, O-Toole SA, Millar EK et al (2010). Inositol polyphosphate 4phosphatase II regulates PI3K/Akt signaling and is lost in human basal-like breast cancers. Proc Nati Acad Sci U S A 107(51):22231-22236.

21. Porta C, Paglino C, Mosca A (2014). Targeting PI3K/Akt/mTOR Signaling in Cancer.Front Oncology 14;4:64-64.

22. Chen WS, Xu P-Z, Gottlob K, Chen M-L, Sokol K et al (2001). Growth retardation and increased apoptosis in mice with homozygous disruption of the Akt1 gene. Genes \&development 15(17):22032208.

23. Cho H, Thorvaldsen JL, Chu Q, Feng F, Birnbaum MJ (2001). Akt1/PKBalpha is required for normal growth but dispensable for maintenance of glucose homeostasis in mice. J Biol Chem 276(42):38349-52.

24. Cho H, Mu J, Kim JK, Thorvaldsen JL, Chu Q, Crenshaw EB $3^{\text {rd }}$, Kaestner KH (2001). Insulin resistance and a diabetes mellitus-like syndrome in mice lacking the protein kinase Akt2 (PKB beta). Science 292(5522):1728-31.

25. Garofalo RS, Orena SJ, Rafidi K, Torchia AJ, Stock JL, Hildebrandt AL, Coskran T, Black SC, Bress DJ, Wicks JR, McNeish JD, Coleman KG (2003). Severe diabetes, age dependent loss of adipose tissue, 
and mild growth deficiency in mice lacking Akt2/PKB beta. J Clin Invest 112(2):197-208.

26. Easton RM, Cho H, Roovers K, Shineman DW, Mizrahi M, Forman MS, Lee VM, Szabolcs M, de Jong $\mathrm{R}$, Oltersdorf T, Ludwig T, Efstratiadis A, Birnbaum MJ (2005). Role for Akt3/protein kinase B gamma in attainment of normal brain size. Mol Cell Biol 25(5):1869-78.

27. Schultze SM, Jensen J, Hemmings BA, Tschopp O, Niessen M (2011). Promiscuous affairs of $\mathrm{PKB} / \mathrm{AKT}$ isoforms in metabolism. Arch Physiol Biochem 117(2):70-7.

28. Dummler B, Hemmings BA (2007). Physiological roles of PKB/Akt isoforms in development and disease. Biochem Soc Trans 35(Pt 2):231-5.

29. Chin YR, Toker A (2010). The actin-bundling protein palladin is an Akt1-specific substrate that regulates breast cancer cell migration. Mol Cell 38(3):333-44.

30. Liu H, Radisky DC, Nelson CM,Zhang H, Fata JE, Roth RA, Bissell MJ (2006). Mechanism of Akt1 inhibition of breast cancer cell invasion reveals a protumorigenic role for TSC2. Proc Natl Acad Sci U $S$ A 103(11):4134-9.

31. Hart JR, Vogt PK (2011). Phosphorylation of AKT: a mutational analysis. Oncotarget 2(6):467-76.

32. Yang WL, Wang J, Chan CH, Lee SW, Campos AD, Lamothe B, Hur L, Grabiner BC, Lin X, Darnay BG, Lin HK (2009). The E3 ligase TRAF6 regulates Akt ubiquitination and activation. Science 325(5944):1134-8.

33. Santi SA, Lee H (2010). The Akt isoforms are present at distinct subcellular locations. Am J Physiol Cell Physiol 298(3):C580-91.

34. Gonzalez E, McGraw TE (2009). Insulin-modulated Akt subcellular localization determines Akt isoform-specific signaling. Proc Natl Acad Sci U S A 106(17):7004-9.

35. Hers I, Vincent EE, Tavare JM (2011). Akt signalling in health and disease. Cell Signa/23(10):151527.

36. Parikh C, Janakiraman V, Wu WI, Foo CK, Kljavin NM, Chaudhuri S, Stawiski E, Lee B, Lin J, Li H, Lorenzo MN, Yuan W, Guiilory J, Jackson M, Rondon J, Franke Y, Bowman KK, Sagolla M, Stinson J, Wu TD, Wu J, Stokoe D, Stern HM, Brandhuber BJ, Lin K, Skelton NJ, Seshagiri S (2012). Disruption of $\mathrm{PH}$ kinase domain interactions leads to oncogenic activation of AKT in human cancers. Proc Natl AcadSci U S A 109(47):19368-73.

37. Poduri A, Evrony GD, Cai X, Elhosary PC, Beroukhim R, Lethinen MK, Hills LB, Heinzen EL, Hill A, Hill RS, Barry BJ, Bourgeois BF, Riviello JJ, Barkovich AJ, Black PM, Ligon KL, Walsh CA (2012). Somatic activation of AKT3 causes hemispheric developmental brain malformations. Neuron 74(1):41-8.

38. Tan K, Kimber WA, Luan J, Soos MA, Semple RK, Wareham NJ, O"Rahilly S, Barroso I (2007). Analysis of genetic variation in Akt2/PKB-beta in severe insulin resistance, lipodystrophy, type 2 diabetes, and related metabolic phenotypes. Diabetes 56(3):714-9.

39. Xu X, Shakon M, Nagano H, Hiraoka N, Yamamoto H, Hayashi N, Dono K, Nakamori S, Umeshita K, Ito Y, Matsuura N, Monden M (2004). Akt2 expression correlates with prognosis of human hepatocellular carcinoma. Oncol Rep 11(1):25-32. 
40. Wang J, Zhao W, Guo H, Fang Y, Stockman SE, Bai S, Ng PK, Li Y, Yu Q, Lu Y, Jeong KJ, Chen X, Gao M, Liang J, Li W, Tian X, Jonasch E, Mills GB, Ding Z (2018). AKT isoform-specific expression and activation across cancer lineages. BMC Cancer 18(1):742.

41. Grottke A, Ewald F, Lange T, Dominik N, Herzberger C, Hoppner F, Nashan B, Schumacher U, Jucker M (2016). Downregulation of AKT3 Increases Migration and Metastasis in Triple Negative Breast Cancer Cells by Upregulating S100A4. PloS One 11(1):e0146370-e0146370.

42. Irie HY, Pearline RV, Grueneberg D, Hsia M, Ravichandran P, Kothari N, Natesan S, Brugge JS (2005). Distinct roles of Akt1 and Akt2 in regulating cell migration and epithelial-mesenchymal transition. $J$ Cell Biol 171(6):1023-1034.

43. Chin YR, Yoshida T, Marusyk A, Beck AH, Polyak K, Toker A (2014). Targeting Akt3 signaling in triple negative breast cancer. Cancer Res 74(3):964-973.

44. Gjerdrum C, Tiron C, Hoiby T, Stefansson I, Haugen H, Sandal T, Collett K, Li S, McCormack E, Gjertsen BT, Micklem DR, Akslen LA, Glackin C, Lorens JB (2010). Axl is an essential epithelial-to mesenchymal transition-induced regulator of breast cancer metastasis and patient survival. Proc Natl Acad Sci U S A 107(3):1124-1129.

45. Lebert JM, Lester R, Powell E, Seal M, McCarthy J (2018). Advances in the systemic treatment of triple-negative breast cancer. Curr Oncol (Toronto, Ont.) 25(Suppl 1):S142-S150.

46. Chen QX, Wang XX, Lin PY, Zhang J, Li JJ, Song CG, Shao ZM (2017). The different outcomes between breast-conserving surgery and mastectomy in triple-negative breast cancer: a populationbased study from the SEER 18 database. Oncotarget 8(3):4773-4780.

47. Ecimovic P, McHugh B, Murray D, Doran P, Buggy DJ (2013). Effects of sevoflurane on breast cancer cell function in vitro. Anticancer Res 33(10):4255-60.

48. Kvolik S, Dobrosevic B, Marczi S, Prlic L, Glavas-Obrovac L (2009). Different apoptosis ratios and gene expressions in two human cell lines after sevoflurane anaesthesia. Acta Anaesthesiol Scand 53(9):1192-9.

49. Kvolik S, Glavas-Obrovac L, Bares V, Karner I (2005). Effects of inhalation anesthetics halothane, sevoflurane, and isoflurane on human cell lines. Life Sci 77(19):2369-83.

50. Liang H, Gu MN, Yang CX, Wang HB, Wen XJ, Zhou QL (2011). Sevoflurane inhibits proliferation, induces apoptosis, and blocks cell cycle progression of lung carcinoma cells. Asian Pac J Cancer Prev 12(12):3415 - 20.

51. Gonzalez E, McGraw TE (2009). The Akt kinases: isoform specificity in metabolism and cancer. Cell cycle (Georgetown, Tex.) 8(16):2502-2508.

52. Clark AR, Toker A (2014). Signalling specificity in the Akt pathway in breast cancer. Biochem Soc Trans 42(5):1349-1355.

53. Danielsson F, Peterson MK, Caldeira Araujo H, Lautenschlanger F, Gad AKB (2018). Vimentin Diversity in Health and Disease. Cells 7(10):pii:E147.

54. Yu W, Yang L, Li T, Zhang Y (2019). Cadherin Signaling in Cancer: Its Functions and Role as a Therapeutic Target. Front Onco/ 9: 
55. Jia W, Zhu J, Martin TA, Jiang A, Sanders AJ, Jiang WG (2015). Epithelial-mesenchymal Transition (EMT) Markers in Human Pituitary Adenomas Indicate a Clinical Course. Anticancer Res 35(5):263543.

56. Gargini R, Cerliani JP, Escoll M, Anton IM, Wandosell F (2015). Cancer stem cell-like phenotype and survival are coordinately regulated by Akt/FoxO/Bim pathway. Stem Cells 33(3):646-660.

57. Generali D, Berruti A, Brizzi MP, Campo L, Bonardi S, Wigfield S, Bersiga A, Allevi G, Milani M, Aguggini S, Gandolf V, Dogliotti L, Bottini A, Harris AL, Fox SB (2006). Hypoxia-Inducible Factor-1A Expression Predicts a Poor Response to Primary ChemoendocrineTherapy and Disease-Free Survival in Primary Human Breast Cancer. Clin Cancer Res 12(15):4562-4568.

58. Schindl M, Schoppmann SF, Samonigg H, Hausmaninger H, Kwasny W, Gnant M, Jakesz R, Kuista E, Birner P, Oberhuber G, Austrian Breast and Colorectal Cancer Study Group (2002). Over-expression of hypoxia-inducible factor1alpha is associated with an unfavorable prognosis in lymph node-positive breast cancer. Clin Cancer Res 8:1831-7.

59. Imai T, Horiuchi A, Wang C, Oka K, Ohira S, Nikaido T, Koshi I (2003). Hypoxia attenuates the expression of E-cadherin via up-regulation of SNAIL in ovarian carcinoma cells. J. Pathol 163(4):1437-1447.

\section{Supplemental Figure Legends}

Supp. Fig. 1 Morphologycal aspects of MDA-MB 231 cells. A. 24 hrs; B. 72 hrs; (1. Untreated; 2-5 Treated with $0.5 \mathrm{mM}, 1 \mathrm{mM}, 2 \mathrm{mM}, 4 \mathrm{mM}$ )

Supp. Fig. 2 Akt1 expression. A. MCF-10a; B. MDA-MB 231; (Control - Untreated, Sevoflurane - Treated $2 \mathrm{mM})$

Supp. Fig. 3 Akt2 expression. A. MCF-10a; B. MDA-MB 231; (Control - Untreated, Sevoflurane - Treated $2 \mathrm{mM})$

Supp. Fig. 4 Akt3 expression. A. MCF-10A; B. MDA-MB 231; (Control - Untreated, Sevoflurane - Treated $2 \mathrm{mM})$

Supp. Fig. 5 Vimentin expression. A. MCF-10A; (Control - Untreated, Sevoflurane - Treated 2mM)

Supp. Fig. 5 Vimentin expression. B. MDA-MB 231; (Control - Untreated, Sevoflurane - Treated 2mM)

\section{Figures}


A.

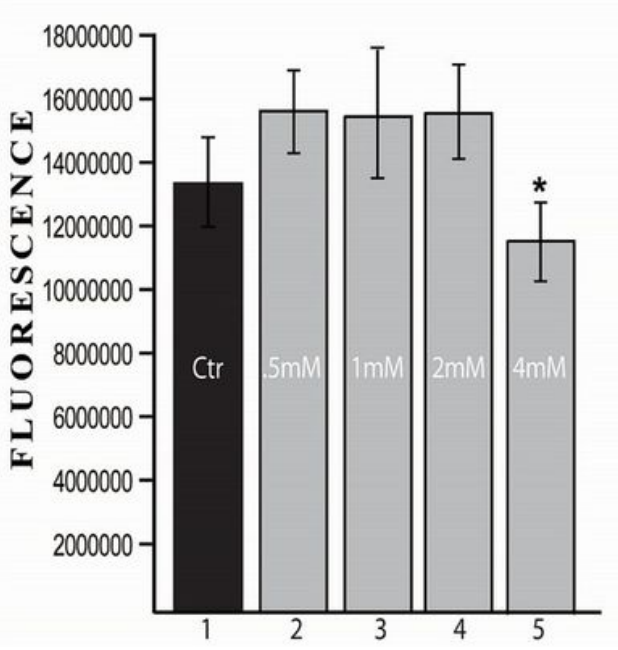

B.

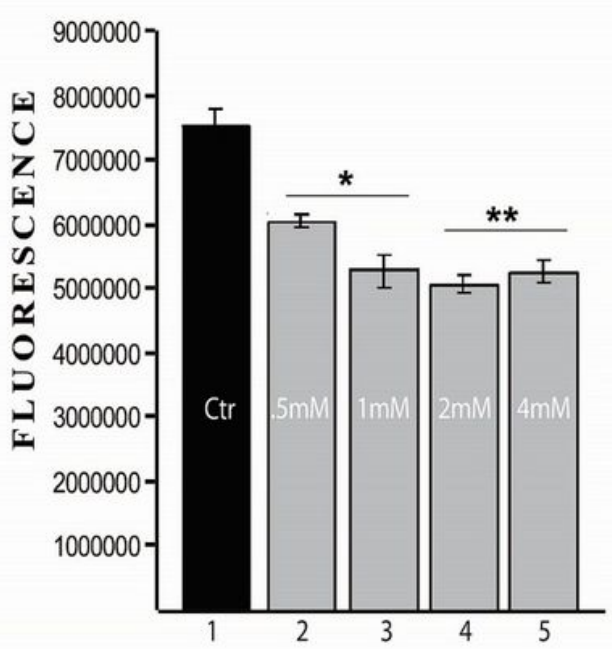

C.

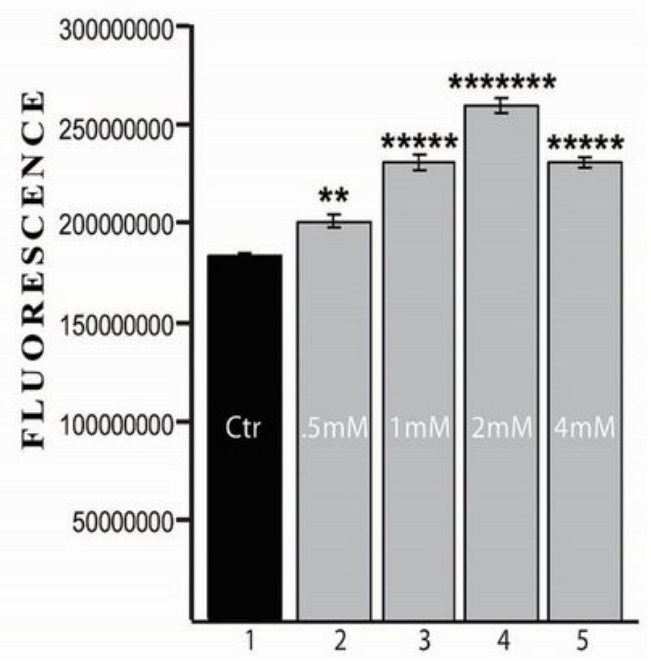

Figure 1

Cell viability. A. Normal mammary epithelial cells MCF10a; B. Human breast adenocarcinoma cell line MDA-MB 231 at 24h; C. Human breast adenocarcinoma cell line MDA-MB 231 at 72h; (1. Untreated; 2-5 Treated with $0.5 \mathrm{mM}, 1 \mathrm{mM}, 2 \mathrm{mM}, 4 \mathrm{mM}$ sevoflurane), ${ }^{*} p<0.05 ; * \star p<0.005 ; * \star \star \star \star p<0.000005$; $\star * \star \star \star * * \mathrm{p}<0.00000005$

A.

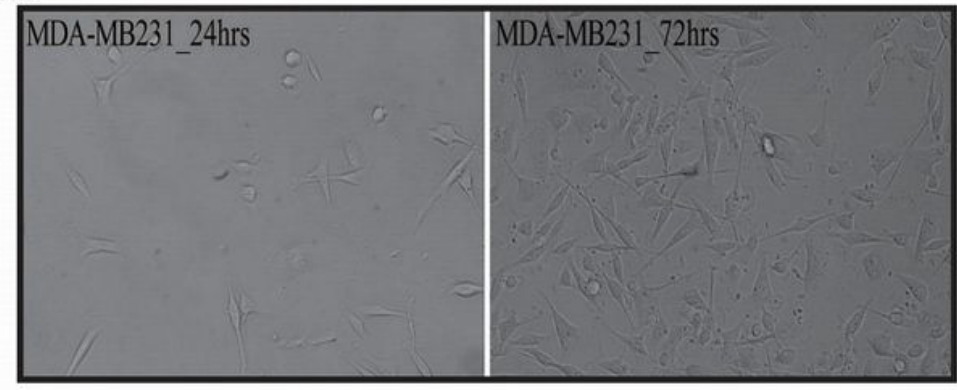

B.

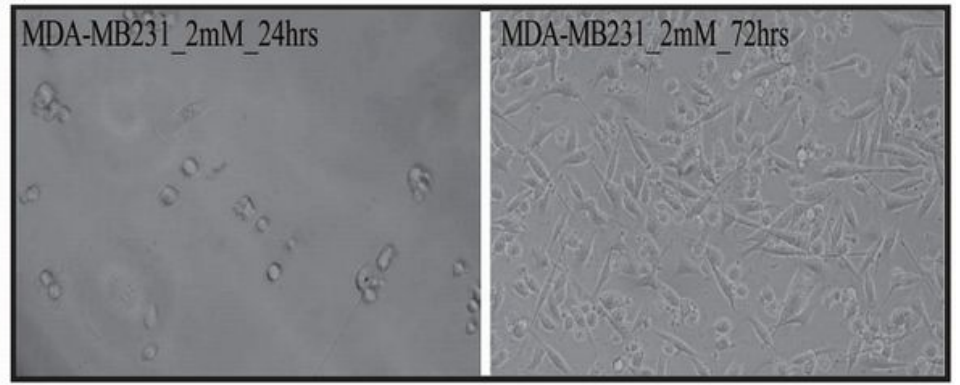

Figure 2

Morphologycal aspects of MDA-MB 231 cells. A. Untreated; B. Treated. 10X 


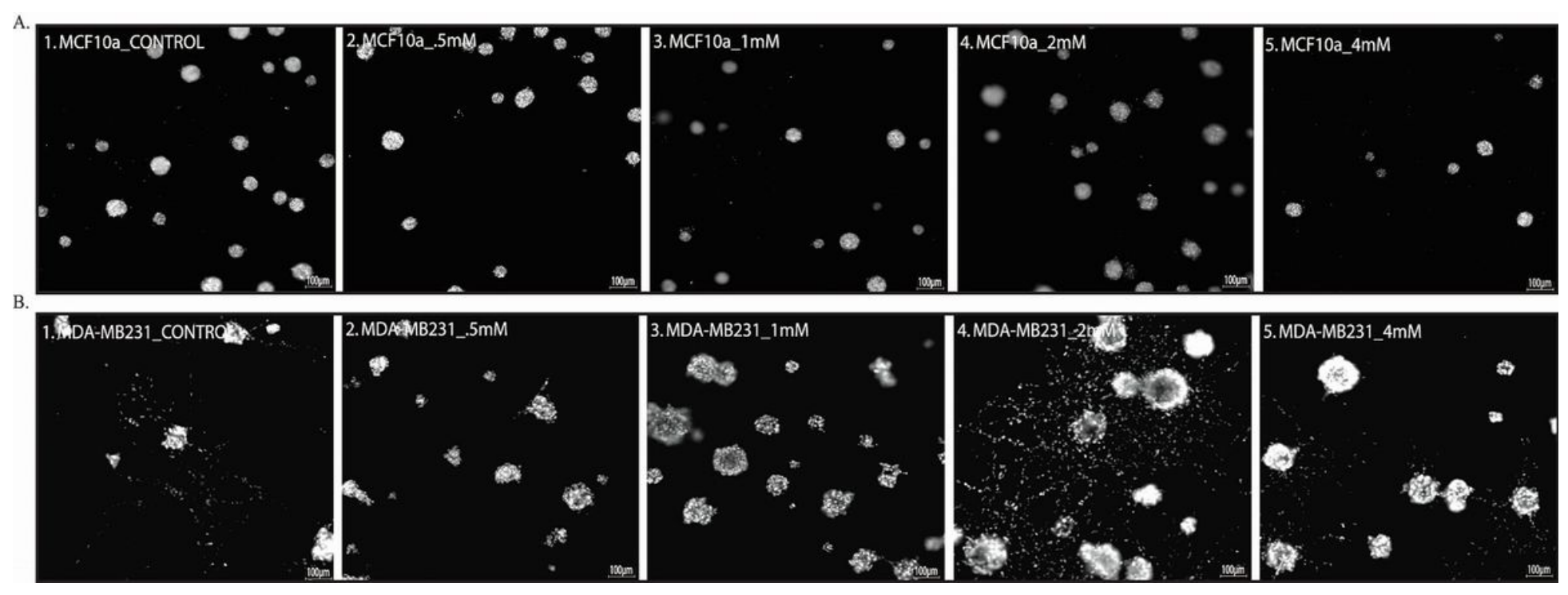

Figure 3

Morphologycal aspects of 3D matrigel culture. A. Normal mammary epithelial cells MCF10A; B. Human breast adenocarcinoma cell line MDA-MB231; (1. Untreated; 2-5 Treated with 0.5mM, 1mM, 2mM, $4 \mathrm{mM}$ sevoflurane).

A.

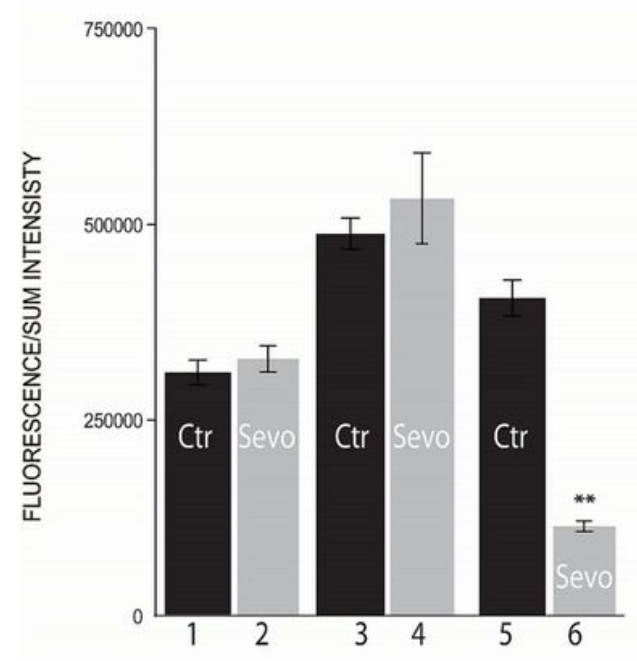

B.

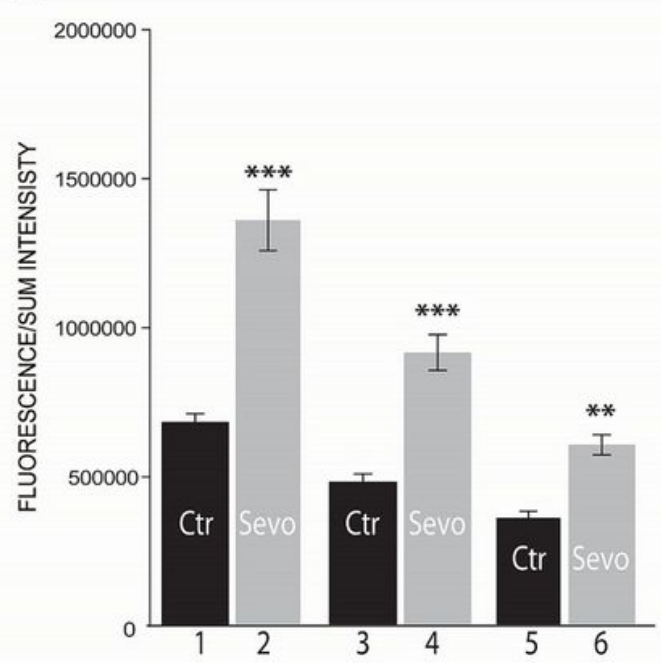

C.

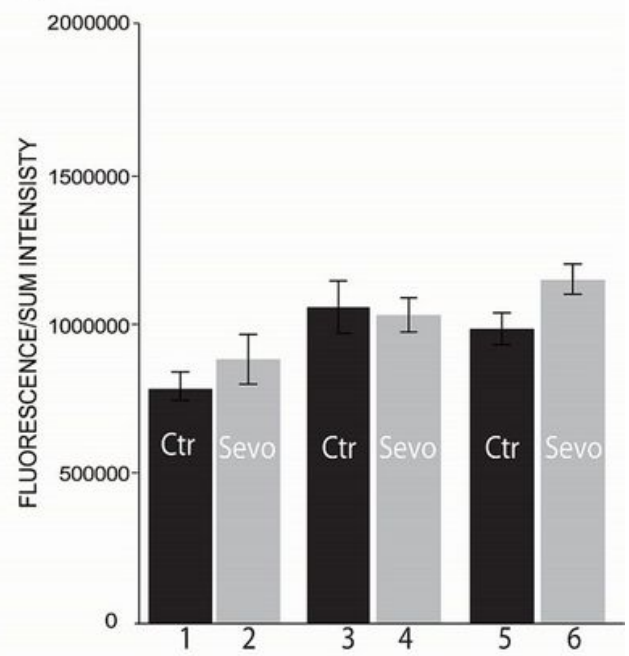

Figure 4

Level of AKT isoformes in MCF-10A. A. AKT1 expression level; B. AKT2 expression level; C. AKT3 expression level (1,2-6 h; 3,4-24 h; 5,6-72 h; Ctr-untreated cells; Sevo- treated cells with $2 \mathrm{mM}$ sevoflurane; h-hours). ${ }^{* \star} p<0.005 ; * \star * p<0.0005$. 
A.

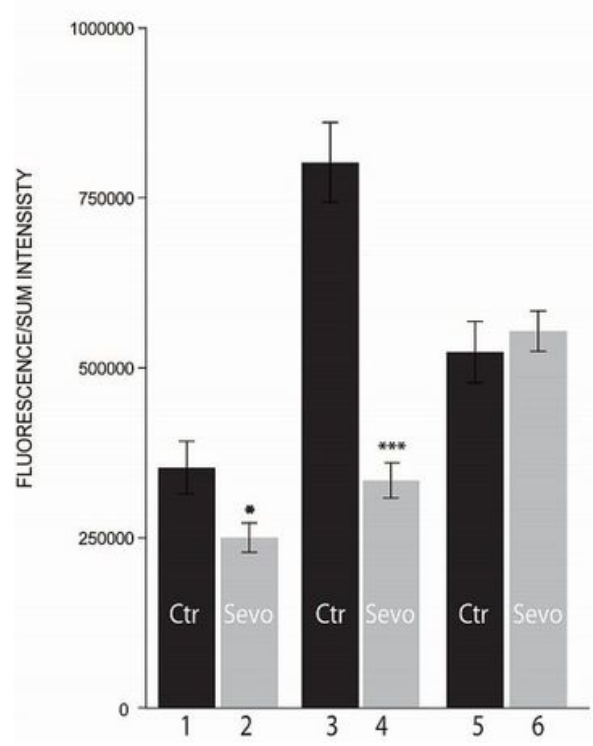

B.

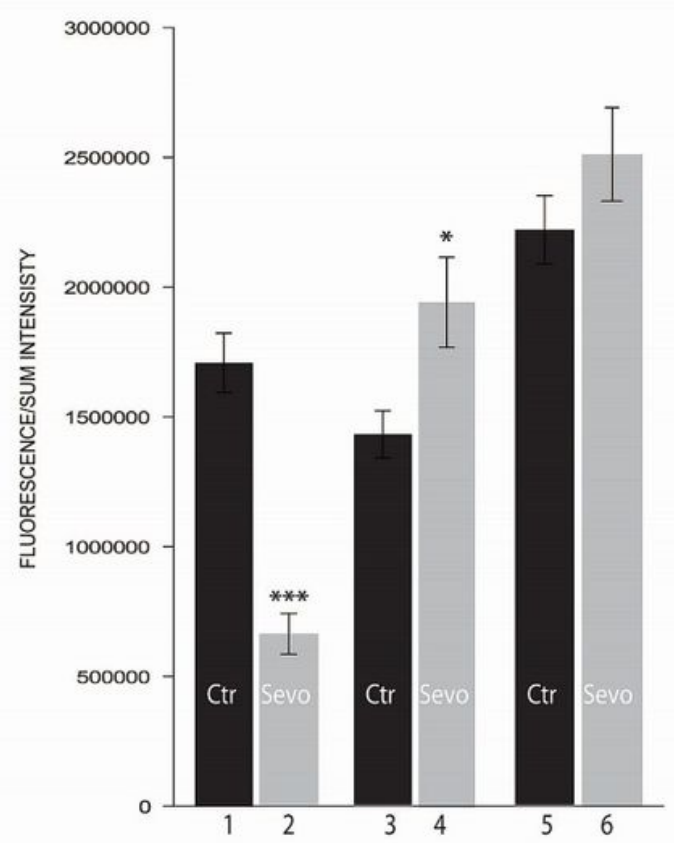

c.

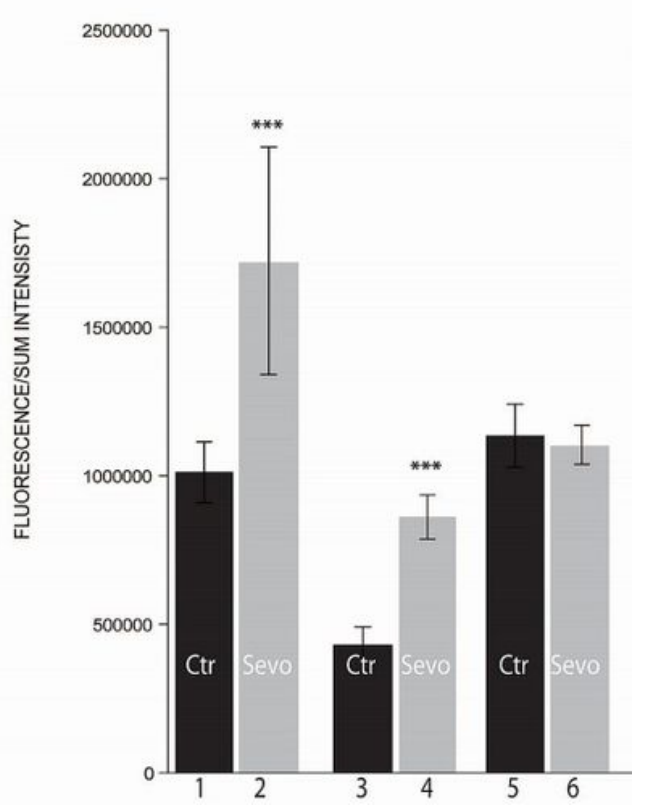

Figure 5

Level of AKT isoformes in MDA-MB231. A. AKT1 expression level; B. AKT2 expression level; C. AKT3 expression level (1,2-6 h; 3,4-24 h; 5,6-72 h; Ctr-untreated cells; Sevo- treated cells with $2 \mathrm{mM}$ sevoflurane; h-hours) ${ }^{*} \mathrm{p}<0.05 ; * \star * \mathrm{p}<0.0005$.

A.

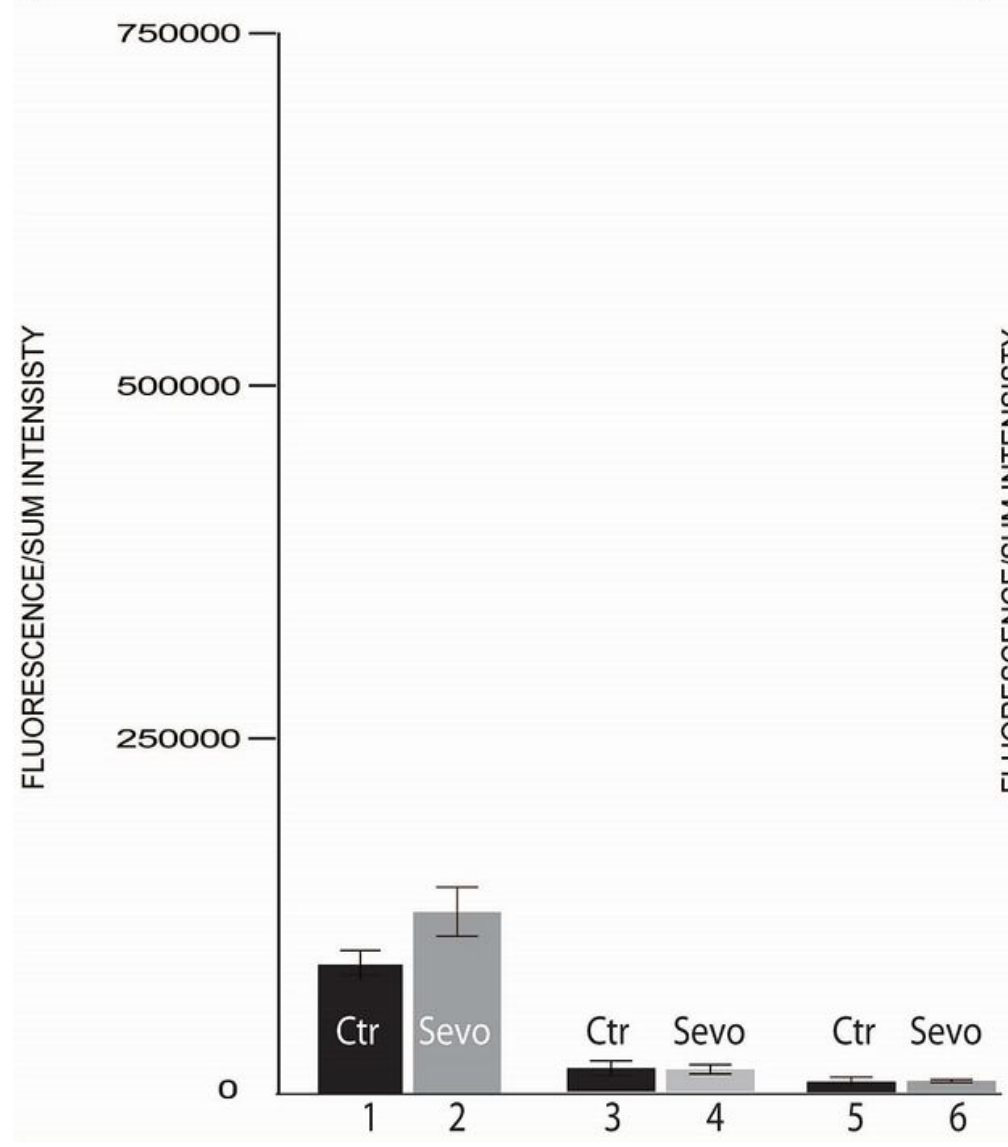

B.

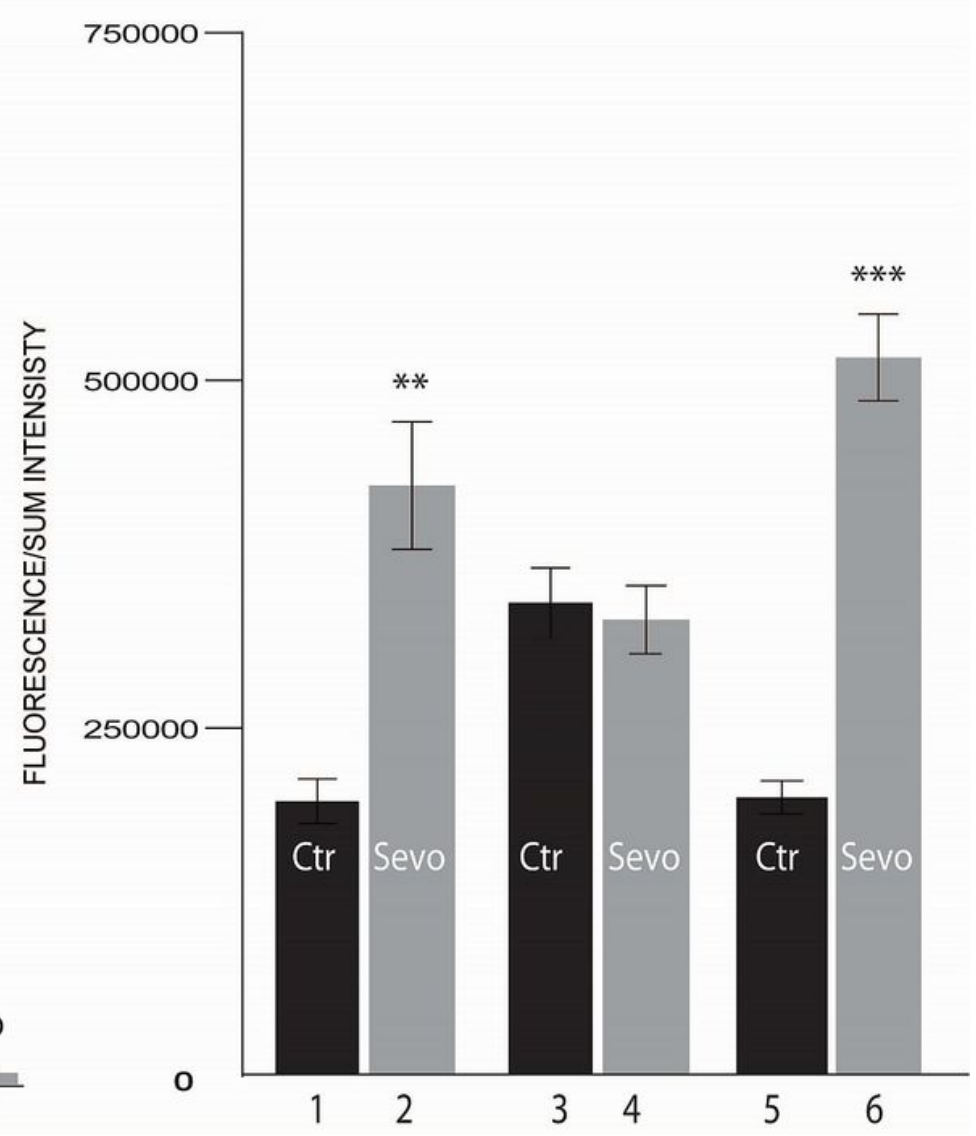




\section{Figure 6}

Level of Vimentin. A. Normal mammary cells MCF-10A B. Human breast adenocarcinoma cell line MDAMB231 (1,2-6 h; 3,4-24 h; 5,6-72 h; Ctr-untreated cells; Sevo- treated cells with 2mM sevoflurane; $h$ hours). $* * p<0.005 ; * * * p<0.0005$.

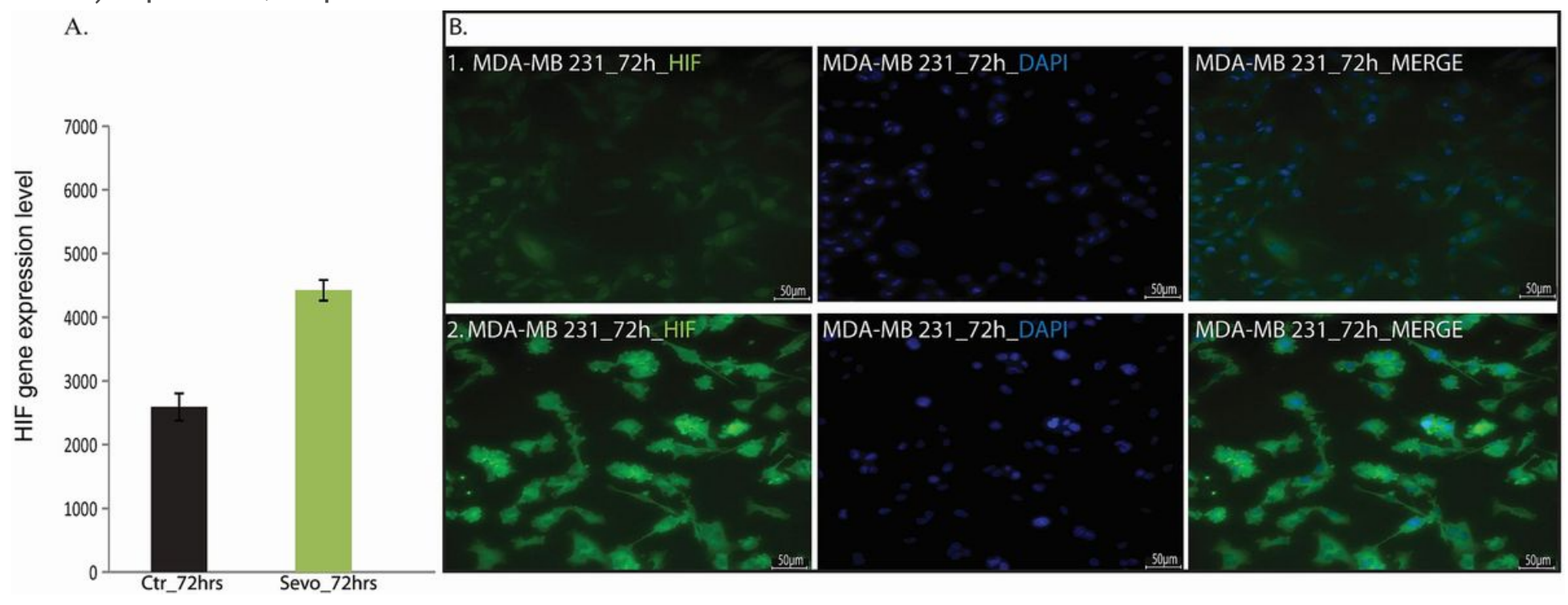

\section{Figure 7}

HIF-1a expression. A. HIF-1a gene expression level; B. HIF-1a protein expression level; (1. 6 h postsevoflurane exposure; $2.72 \mathrm{~h}$ post-sevoflurane exposure).

\section{Supplementary Files}

This is a list of supplementary files associated with this preprint. Click to download.

- SUPPLIMENTARYFIG.1.jpg

- SUPPLIMENTARYFIG.4.jpg

- SUPPLIMENTARYFIG.2.jpg

- SUPPLIMENTARYFIG.5B.jpg

- SUPPLIMENTARYFIG.3.jpg

- SUPPLIMENTARYFIG.5A.jpg 